\title{
The Effect of High Day and Low Night Temperature on Pollen Production, Pollen Germination and Postharvest Quality of Tomatoes
}

\author{
B. Khanal, A. Suthaparan, A. B. Hückstädt, A. B. Wold, Leiv Mortensen, H. R. Gislerød \\ Department of Plant and Environmental Sciences, The Norwegian University of Life Sciences, Ås, Norway. \\ Email: lei-mo@online.no
}

Received April 25 $5^{\text {th }}$ 2013; revised May 26 ${ }^{\text {th }}, 2013$; accepted June $15^{\text {th }}, 2013$

Copyright (C) 2013 B. Khanal et al. This is an open access article distributed under the Creative Commons Attribution License, which permits unrestricted use, distribution, and reproduction in any medium, provided the original work is properly cited.

\begin{abstract}
Temperature integration where high day temperatures are compensated by lower night temperatures is one strategy that can be used to reduce energy consumption in greenhouses. Crop tolerance to temperature variation is a prerequisite for using such a strategy. Greenhouse experiments were conducted on tomatoes cvs, Capricia, Mecano and Cederico in order to investigate the effect of different day/night temperature regimes $\left(24 / 17,27 / 14\right.$ and $\left.30 / 11^{\circ} \mathrm{C}\right)$ where the same mean temperature was maintained for the production and germination of pollen. In addition, fruit quality as determined by fruit firmness, dry matter content, soluble solids, titratable acids, and $\mathrm{pH}$ was examined at harvest and after seven and 14 days of storage. The $30 / 11^{\circ} \mathrm{C}$ treatment significantly increased pollen production and germination compared to the $24 / 17^{\circ} \mathrm{C}$ treatment, while the $27 / 14^{\circ} \mathrm{C}$ treatment was generally in between the other two treatments. Fruits grown at the $27 / 14^{\circ} \mathrm{C}$ treatment were significantly firmer, while fruits grown at $24 / 17^{\circ} \mathrm{C}$ had higher dry matter content, soluble solids, and titratable acids compared to the other treatments. There were significant differences between cultivars with respect to firmness, dry matter, titratable acidity, and $\mathrm{pH}$. The quality of the fruits changed during storage, but the storability of the tomatoes was not affected by preharvest temperature treatments. The overall conclusion was that the $27 / 14^{\circ} \mathrm{C}$ treatment was superior to the other two temperature treatments with respect to the studied parameters.
\end{abstract}

Keywords: Daily Mean Temperature; Day Temperature (DT); Night Temperature (NT); Pollen; Temperature Integration; Dry Matter; pH; Titratable Acids; Soluble Solids; Postharvest; Tomato

\section{Introduction}

Temperature integration where high day temperatures are compensated by lower night temperatures is an important means of reducing energy consumption in greenhouses [1]. Temperature increases with increasing irradiance to a maximum accepted level at which ventilation takes place, and the night temperature is reduced sufficiently to secure an optimal mean temperature level. Depending on the season and weather conditions, energy savings of more than $20 \%$ can be achieved by means of such temperature control $[2,3]$. However, the effectiveness of temperature integration depends on the plant's ability to tolerate temperature variation. Results of studies conducted on a wide range of vegetables including tomato and ornamentals, have shown that within a certain temperature range, growth and development respond to the mean daily temperature rather than to the day/night temperature variation [4$6]$.
Tomato is an important vegetable worldwide, in which temperature is known to affect various physiological aspects, including pollen viability and fruit quality [7]. It has been reported that pollen germination was significantly reduced when tomatoes were grown at temperatures of up to $32 / 26^{\circ} \mathrm{C}$ day/night temperature [8]. Tomato quality includes visual characteristics such as color and firmness, nutritional constituents, and organoleptic characteristics such as aroma compounds and the content of sugar and acids. Dorais et al. (2001) reviewed the quality of greenhouse tomatoes [9], and the fruit quality might be affected by high and low temperatures as well as the differences between day and night temperatures [10]. The effect of preharvest and postharvest factors, including temperature, on soluble solids in tomatoes has been reviewed [11]. For cherry tomatoes, the percentage dry weight, glucose, and fructose were found to be higher in fruits developed under high temperature variation (30/ 
$15^{\circ} \mathrm{C}$ day/night), while lower levels of citric and malic acid were reported [12]. Nevertheless, few works have included the effect of preharvest factors on the quality and storability of tomatoes [13]. It has been concluded that tomato plants can tolerate air temperature fluctuations of up to $6^{\circ} \mathrm{C}$ from the daily mean of $18.7^{\circ} \mathrm{C}$ with respect to growth and flowering [14]. Little is known about the effect of temperature variation, with a fixed daily mean temperature, on pollen growth, fruit quality, and storability. The aim of this study was therefore to examine the effect of different day/night temperature variations on pollen production and germination as well as on the postharvest fruit quality of three tomato cultivars.

\section{Materials and Methods}

\subsection{Plant Material and Environmental Conditions}

Seeds of tomato (Solanum lycopersicum "Capricia", "Mecano" and "Cederico") were sown in 12-cm plastic pots filled with peat (VEKSTTORV, Ullensaker Almenning, Nordkisa, Norway) and perlite (Substraat, RHD, The Netherlands) mixture (3:1). Plants were irrigated with a complete nutrient solution (Superba ${ }^{\mathrm{TM}}$ Red $(50 \%)$ and Calcinite (50\%), Yara AS, Oslo, Norway) as necessary. Temperature (day and night) and relative air humidity (RH) were set to $20^{\circ} \mathrm{C}$ (a mean of $19.7^{\circ} \mathrm{C}$ observed) and $75 \%$ (a mean of $72 \%$ observed). Supplemental lighting at a photon flux density (PFD) of $100 \mu \mathrm{mol} \mathrm{m} \mathrm{m}^{-2} \cdot \mathrm{s}^{-1}$ was provided by high-pressure sodium lamps (HPS) (Lucalox LU400/XO/T/40, GE lighting, Budapest, Hungary) when the outside level fell below $100 \mathrm{~W} \cdot \mathrm{m}^{-2}$ global radiation, to maintain 20-hour day length. The PFD was measured by a quantum meter Model QMSW-SS (Apogee instruments Inc., Logan, UT, USA). Once the tomato plants had developed five leaves, they were transplanted into 30-liter plastic pots filled with a peat and perlite mixture (7:3). At the appearance of the first inflorescence, the plants were moved to the experimental conditions.

The experiment was conducted at the Norwegian University of Life Sciences (UMB), Ås, Norway $\left(59^{\circ} 40^{\prime} \mathrm{N}\right.$ and $10^{\circ} 46^{\prime} \mathrm{E}$ ) from March to July 2011, in three greenhouse compartments located beside each other. The ventilation temperature for the different compartments was $24^{\circ} \mathrm{C}, 27^{\circ} \mathrm{C}$, and $30^{\circ} \mathrm{C}$ during the day, and ventilation was used at night to reach temperatures of $17^{\circ} \mathrm{C}, 14^{\circ} \mathrm{C}$, and $11^{\circ} \mathrm{C}$, respectively. Solar radiation, air temperature, and $\mathrm{RH}$ in the greenhouse compartments were recorded at five-minute intervals by a Priva greenhouse computer (Priva, Zijlweg, The Netherlands). The hourly mean values (mean of 12 readings) of these variables were used to calculate the mean day, night, and daily temperatures.
During the experimental period, the mean day temperatures in the three compartments were $23.7^{\circ} \mathrm{C} \pm 1.8^{\circ} \mathrm{C}$, $26.4^{\circ} \mathrm{C} \pm 1.3^{\circ} \mathrm{C}$, and $29.2^{\circ} \mathrm{C} \pm 2.0^{\circ} \mathrm{C}$, and the mean night temperatures were $16.4^{\circ} \mathrm{C} \pm 0.1^{\circ} \mathrm{C}, 13.9^{\circ} \mathrm{C} \pm 0.1^{\circ} \mathrm{C}$, and $11.5^{\circ} \mathrm{C} \pm 0.5^{\circ} \mathrm{C}$, respectively. The temperature, air humidity, and $\mathrm{CO}_{2}$ concentration were measured at plant level. During the experimental period, the day length varied from 11 hours in March to 19 hours in June, and no supplementary lighting was used. At sunrise, the vents were closed and the temperature was allowed to increase by means of solar radiation. Night temperatures were achieved by natural cooling through ventilation or by heating. The air humidity was maintained at $75 \% \pm 5 \%$ day and night through ventilation or by the application of mist. The $\mathrm{CO}_{2}$ concentration (as measured every ten minutes) by a Priva infrared gas analyzer) was set to $700 \mu \mathrm{mol} \cdot \mathrm{mol}^{-1}$ during the light period when the vents were closed, and to $385 \mu \mathrm{mol} \cdot \mathrm{mol}^{-1}$ during ventilation or during the dark period. The mean concentration for the whole experimental period was $628 \pm 82,662 \pm 77$, and $715 \pm 76$ $\mu \mathrm{mol} \cdot \mathrm{mol}^{-1}$ at the $24 / 17^{\circ} \mathrm{C}, 27 / 14^{\circ} \mathrm{C}$, and $30 / 11^{\circ} \mathrm{C}$ treatments, respectively. The temperature and $\mathrm{CO}_{2}$ concentration during a period of six or 12 days at the time of flowering are summarized (Table 1) as well as the temperature during the four weeks prior to harvest (Table 2). The photosynthetic active radiation (PAR) inside the greenhouse (about $50 \%$ of the outside radiation) during the 12 days was $13.3 \pm 3.1(17-28$ March) and $12.2 \pm 6.4 \mathrm{~mol}$ $\mathrm{m}^{-2}$. day $^{-1}$ (29 March-10 April) for truss number four and six, respectively. The photosynthetic active radiation was $17 \pm 6,20 \pm 6$ and $20 \pm 10 \mathrm{~mol} \cdot \mathrm{m}^{-2} \cdot \mathrm{day}^{-1}$ in April, May and June, respectively. The conversion factor from global radiation (in $\mathrm{MJ} \cdot \mathrm{m}^{-2} \cdot \mathrm{day}^{-1}$ ) to PAR (in $\mathrm{mol} \cdot \mathrm{m}^{-2} \cdot \mathrm{day}^{-1}$ ) was 2.2.

Elemental sulfur was applied for two hours every night. Plants were fertilized daily with four liters (complete saturation of the substrate) of the same nutrient solution as previously described. The nutrient solution had a conductivity of $2.5 \mathrm{mS} \cdot \mathrm{cm}^{-1}$ (DGT Volmatic Type LM20 Serial 9305), and the salinity of the growing medium was $4-5$ $\mathrm{mS} \cdot \mathrm{cm}^{-1}$, using the soil saturated extract (SSE) method.

The plants were pinched above the ninth truss in all temperature treatments. The fourth and sixth trusses as counted from the bottom of the plants were selected for the following analysis: The first flower was assessed for pollen production and the second flower for pollen germination one day after opening, and the third flower for pollen production and the fourth flower for pollen germination four days after opening. This was done under the same conditions $\left(20^{\circ} \mathrm{C} / 70 \% \mathrm{RH}\right)$ for all three temperature treatments. In addition, the fifth and sixth flowers on the same trusses were used to assess pollen pro- 
Table 1. Day and night temperature (means \pm SD) during a six-day period (from five days before until one day after flower opening) or a twelve-day period (from eight days before until four days after flower opening) in trusses four and six. $\mathrm{CO}_{2}$ concentration is given for the light period.

\begin{tabular}{ccccccccc}
\hline Set temperature $\left({ }^{\circ} \mathrm{C}\right)$ & Truss no. & \multicolumn{3}{c}{ Day temp. $\left({ }^{\circ} \mathrm{C}\right)$} & \multicolumn{2}{c}{ Night temp. $\left({ }^{\circ} \mathrm{C}\right)$} & Mean temp. $\left({ }^{\circ} \mathrm{C}\right)$ & $\begin{array}{c}\mathrm{CO}_{2} \mathrm{conc} \\
\left(\mu \mathrm{mol} \cdot \mathrm{mol}^{-1}\right)\end{array}$ \\
\hline & & & 6 6-day period & 12-day period & 6-day period & 12-day period & 6-day period 12-day period & 6-day/12-day period \\
$24 / 17$ & 4 & $23.7 \pm 1.3$ & $23.9 \pm 1.2$ & $16.4 \pm 0.1$ & $16.3 \pm 0.1$ & 19.1 & 19.2 & $632 \pm 82 / 618 \pm 80$ \\
$27 / 14$ & 4 & $26.0 \pm 1.1$ & $26.4 \pm 1.4$ & $13.9 \pm 0.1$ & $13.8 \pm 0.1$ & 18.2 & 18.4 & $630 \pm 76 / 652 \pm 91$ \\
$30 / 11$ & 4 & $28.7 \pm 2.3$ & $29.1 \pm 2.2$ & $11.4 \pm 0.2$ & $11.1 \pm 0.2$ & 17.5 & 17.7 & $652 \pm 88 / 716 \pm 94$ \\
$24 / 17$ & 6 & $22.3 \pm 2.1$ & $23.5 \pm 2.3$ & $16.5 \pm 0.1$ & $16.6 \pm 0.1$ & 18.9 & 19.3 & $624 \pm 82 / 580 \pm 82$ \\
$27 / 14$ & 6 & $26.2 \pm 2.4$ & $26.4 \pm 2.1$ & $13.9 \pm 0.1$ & $14.1 \pm 0.1$ & 18.4 & 18.9 & $694 \pm 78 / 624 \pm 95$ \\
$30 / 11$ & 6 & $29.5 \pm 2.3$ & $29.3 \pm 2.2$ & $11.1 \pm 0.2$ & $12.0 \pm 0.7$ & 18.1 & 18.5 & $778 \pm 73 / 720 \pm 92$ \\
\hline
\end{tabular}

Table 2. Mean maximum day and minimum night temperature during the four weeks prior to harvesting the tomato fruits of truss number five for three different temperature treatments.

\begin{tabular}{cccc}
\hline $\begin{array}{c}\text { Set day/night } \\
\text { temperature }\left({ }^{\circ} \mathrm{C}\right)\end{array}$ & $\begin{array}{c}\text { Observed day } \\
\text { temperature }\left({ }^{\circ} \mathrm{C}\right)\end{array}$ & $\begin{array}{c}\text { Observed night } \\
\text { temperature }\left({ }^{\circ} \mathrm{C}\right)\end{array}$ & $\begin{array}{c}\text { Mean temperature } \\
\left({ }^{\circ} \mathrm{C}\right)\end{array}$ \\
\hline $24 / 17^{\circ} \mathrm{C}$ & $25.4 \pm 2.2$ & $15.3 \pm 1.4$ & 19.7 \\
$27 / 14^{\circ} \mathrm{C}$ & $27.2 \pm 1.3$ & $14.1 \pm 0.5$ & 19.4 \\
$30 / 11^{\circ} \mathrm{C}$ & $30.1 \pm 2.5$ & $11.3 \pm 0.5$ & 19.6 \\
\hline
\end{tabular}

duction and germination at their respective growth temperatures. Since the solar radiation is quite variable during spring two different trusses were selected in order to cover a longer time period for climate exposure.

\subsection{Pollen Production}

In order to measure pollen production, the flowers were removed and placed in $50 \mathrm{ml}$ centrifuge tubes that were filled with $5 \mathrm{ml}$ of distilled water containing $20 \mu \mathrm{l} \cdot \mathrm{l}^{-1}$ of Tween 20 surfactant (Sigma-Aldrich Chemie $\mathrm{GmbH}$, Steinheim, Germany) (one flower per tube). Tubes were shaken by hand 40 times and the flower was removed. The number of pollen per ml of suspension was calculated in two aliquots of suspension using haemocytometer (HYCOR, Hycor biomedical inc. California, USA) under a light microscope at 100X. Pollen with a diameter of less than $20 \mu \mathrm{m}$ and shrunken pollen were considered undersized or abnormal.

\subsection{Pollen Germination}

For pollen germination, the flowers were picked with their pedicle and held $2 \mathrm{~cm}$ above Petri dishes $(5 \mathrm{~cm}$ in diameter) containing pollen growth media [15]. Flowers were vibrated for five seconds using an electric tooth brush (Philips HX1610 Double cleaning action, China) placed on the flower pedicle. Petri dishes were then sealed and incubated in a growth chamber at $20^{\circ} \mathrm{C}$ and $70 \%$ RH. The day length was 14 hours and $130 \pm 10$ $\mu \mathrm{mol} \cdot \mathrm{m}^{-2} \cdot \mathrm{s}^{-1}$ PFD was supplied by high-pressure mercury lamps (Powerstar HQI-BT $400 \mathrm{~W} / \mathrm{D}$ day light, OSRAM GmbH, Augsburg, Germany). One day after incubation, a piece of the pollen growth media was cut and placed on a microscopic glass slide. A droplet of water was placed on top and covered with cover slips. The samples were then assessed for pollen germination under a light microscope. Pollen containing germ tubes at least half the length of the diameter of the pollen was deemed to have germinated. The first 100 pollens were assessed and the percentage of pollen germination was calculated.

\subsection{Fruit Harvest and Postharvest Quality}

Forty-five tomato fruits from the third and fifth clusters of each cultivar and temperature treatment were harvested at commercial ripening stage based on comparison with color chart scale 6 - 9 (Ctifl, Code Couleur Tomate, France). At harvest (day 0), 15 tomatoes were randomly selected and divided into three replicates each containing five tomatoes. The color and firmness of the fruits were measured using color chart comparison and DUROFEL DFT 100 digital firmness tester (Agro-Technologie, St Etienne du Gres, France), respectively. For firmness measurements, the tip of the digital firmness tester was placed on the surface of each tomato fruit at three different points. The instrument measured the elasticity of the outer fruit flesh within the range from 0 (no resistance or high elasticity) to 100 (high resistance or no elasticity) and firmness is specified as DUROFEL-units. The remaining 30 fruits were stored in darkness at $13^{\circ} \mathrm{C}$ and $85 \%$ RH. After seven and 14 days' storage, 15 fruits were assessed for color and firmness. Immediately after the assessments, $3 \times 5$ fruits were frozen at $-20^{\circ} \mathrm{C}$ pending further analysis. 


\subsection{Dry Matter Content, Soluble Solids, Titratable Acidity, and pH}

For analysis of dry matter, soluble solids, titratable acidity, and $\mathrm{pH}$, frozen tomatoes were thawed overnight at room temperature. Tomato samples were homogenized using a food processor (BRAUN, Germany). For dry matter assessment, six grams of homogenized material was dried at $104^{\circ} \mathrm{C}$ for 24 hours and the dry matter percentage was calculated.

The homogenized samples were filtered $(125 \mathrm{~mm}$, Whatman GmbH, Dassel, Germany) and the filtrates were used for further analysis. For soluble solids measurement, a digital refractometer, Model Atago Palett PR-100 (Atago Co., Ltd., Tokyo, Japan) was first calibrated using distilled water. Then two to three drops of tomato juice were placed on the sensor of the refractometer. Soluble solids were given as a percentage.

Automatic titrator, Model Methrom 716 DMS Titrino and 730 Sample changer (Metrohm Ltd., Herisau, Switzerland) were used for the measurement of titratable acidity. Ten $\mathrm{ml}$ of filtrate was diluted with $50 \mathrm{ml}$ of distilled water. Then sodium hydroxide $(0.1 \mathrm{~N})$ was added to the diluted filtrate to reach $\mathrm{pH}$ of 8.1 . Titratable acidity was calculated as a percentage of citric acid. The $\mathrm{pH}$ was measured using a pH meter (Model 691 PH Meter, Metrohm Ltd., Herisau, Switzerland).

\subsection{Statistical Analysis}

Minitab (version 16) was used to conduct analysis of variance (GLM procedure). Three different day/night temperature combinations and three different varieties were included in the model. Response variable means were compared using Tukey's pairwise comparison test at $\mathrm{P}=$ 0.05 .

\section{Results}

\subsection{Pollen Production (Figure 1)}

The number of normal pollen in the fourth truss one day after flower opening was not significantly affected by day/night temperature, while pollen production in the sixth truss was significantly higher $(\mathrm{p}<0.05)$ at $27 / 14^{\circ} \mathrm{C}$ and $30 / 11^{\circ} \mathrm{C}$ compared to $24 / 17^{\circ} \mathrm{C}$ (Table 3). The number of normal pollen assessed four days after flower opening as a mean of the three cultivars, increased as DT increased/NT decreased above/below $24 / 17^{\circ} \mathrm{C}$ (Table 3). The number of abnormal pollen often increased with increasing DT/decreasing NT, particularly in the $30 / 11^{\circ} \mathrm{C}$ treatment (Table 3). The number of normal pollen was highest in cv. Cederico as measured one day after flower opening in the fourth truss, and in cv. Mecano as meas-

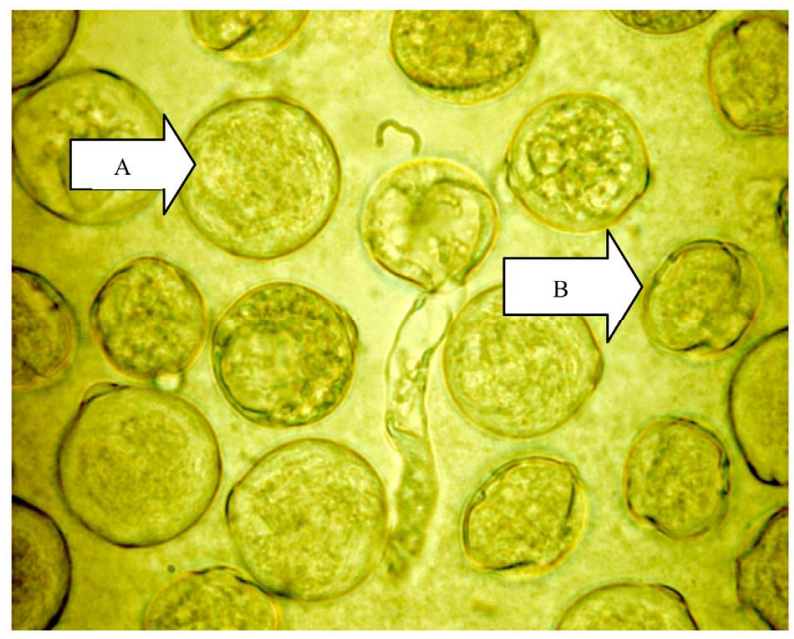

Figure 1. Normal pollen (A) and abnormal pollen (B).

Table 3. Effect of day/night temperature regimes on number of normal and abnormal pollen in different trusses one and four days after flower opening. Values represent means of three cultivars and two replicates $(n=6, \pm S D)$. Different letters within each column indicate significant differences between treatments at $\mathbf{p}<0.05$ level.

\begin{tabular}{cccccc}
\hline $\begin{array}{c}\text { Set } \\
\text { temperature } \\
\left({ }^{\circ} \mathrm{C}\right)\end{array}$ & $\begin{array}{c}\text { Truss } \\
\text { no. }\end{array}$ & \multicolumn{2}{c}{ No. of normal pollen } & \multicolumn{2}{c}{ No. of abnormal pollen } \\
\hline & & 1 day & 4 days & 1 day & 4 days \\
$24 / 17$ & 4 & $28.1 \pm 2.0 \mathrm{a}$ & $40.3 \pm 2.3 \mathrm{~b}$ & $8.7 \pm 0.8 \mathrm{a}$ & $15.0 \pm 1.4 \mathrm{~b}$ \\
$27 / 14$ & 4 & $28.2 \pm 2.2 \mathrm{a}$ & $41.6 \pm 2.3 \mathrm{ab}$ & $9.1 \pm 1.2 \mathrm{a}$ & $18.9 \pm 1.5 \mathrm{ab}$ \\
$30 / 11$ & 4 & $31.3 \pm 2.5 \mathrm{a}$ & $48.8 \pm 1.6 \mathrm{a}$ & $9.3 \pm 0.8 \mathrm{a}$ & $20.5 \pm 1.3 \mathrm{a}$ \\
$24 / 17$ & 6 & $26.4 \pm 1.4 \mathrm{~b}$ & $33.4 \pm 1.7 \mathrm{~b}$ & $11.0 \pm 1.2 \mathrm{~b}$ & $6.7 \pm 0.7 \mathrm{c}$ \\
$27 / 14$ & 6 & $45.9 \pm 2.9 \mathrm{a}$ & $42.1 \pm 2.1 \mathrm{a}$ & $9.3 \pm 0.9 \mathrm{~b}$ & $10.6 \pm 0.6 \mathrm{~b}$ \\
$30 / 11$ & 6 & $51.0 \pm 2.1 \mathrm{a}$ & $43.4 \pm 1.6 \mathrm{a}$ & $15.3 \pm 1.3 \mathrm{a}$ & $15.5 \pm 0.7 \mathrm{a}$ \\
\hline
\end{tabular}

ured four days after flower opening in the sixth truss (data not presented).

\subsection{Pollen Germination}

The pollen germination percentage as measured under the same climate conditions (in a growth chamber) generally increased as DT increased/NT decreased (Table 4). This was the case in both trusses as well as for pollen harvested one or four days after flower opening (Table 4). Similar results were found when pollen germination was measured under growing conditions (Table 4). In growth chamber incubation, pollen germination of the cultivar Cederico was significantly higher four days after flower opening in the sixth truss compared to Capricia and Mecano (data not presented). 


\subsection{Tomato Quality}

Tomatoes grown at $27 / 14^{\circ} \mathrm{C}$ were significantly firmer compared to the other temperature treatments (Table 5). Tomatoes grown at $24 / 17^{\circ} \mathrm{C}$ contained significantly higher amounts of dry matter, soluble solids and titratable acidity, whereas $\mathrm{pH}$ was higher in tomatoes grown at $30 / 11^{\circ} \mathrm{C}$. The cultivars Capricia and Mecano had significantly firmer fruits compared to Cederico. No significant differences were found between the cultivars with respect to soluble solids. Significant differences were observed between the cultivars with respect to dry matter, titratable acidity, and $\mathrm{pH}$. Fruit firmness decreased significantly during storage. Dry matter, soluble solids, and $\mathrm{pH}$ remained stable during storage, whereas titratable acidity decreased significantly from day seven to day 14 . Visually observed the tomatoes produced at $30 / 11^{\circ} \mathrm{C}$ were pale in color compared to tomatoes produced in the other

Table 4. Effect of day/night temperature regimes on percentage pollen germination as measured under the same conditions in a growth chamber and under growing conditions one day and four days after flower opening. Values represent means of three cultivars and two replicates $(n=6$, \pm SD).

\begin{tabular}{cccccc}
\hline $\begin{array}{c}\text { Set } \\
\text { temperature } \\
\left({ }^{\circ} \mathrm{C}\right)\end{array}$ & $\begin{array}{c}\text { Truss } \\
\text { no. }\end{array}$ & \multicolumn{2}{c}{$\begin{array}{c}\text { Same conditions } \\
\text { in growth chamber }\end{array}$} & \multicolumn{2}{c}{$\begin{array}{c}\text { At growing } \\
\text { conditions }\end{array}$} \\
\hline & & 1 day & 4 days & 1 day & 4 days \\
$24 / 17$ & 4 & $26.4 \pm 1.8 \mathrm{~b}$ & $19.1 \pm 1.7 \mathrm{~b}$ & $15.9 \pm 1.7 \mathrm{~b}$ & $15.1 \pm 1.5 \mathrm{c}$ \\
$27 / 14$ & 4 & $36.5 \pm 2.9 \mathrm{a}$ & $24.5 \pm 2.2 \mathrm{~b}$ & $17.0 \pm 1.2 \mathrm{~b}$ & $23.6 \pm 1.4 \mathrm{~b}$ \\
$30 / 11$ & 4 & $41.1 \pm 3.5 \mathrm{a}$ & $34.8 \pm 2.8 \mathrm{a}$ & $37.0 \pm 2.1 \mathrm{a}$ & $37.0 \pm 2.1 \mathrm{a}$ \\
$24 / 17$ & 6 & $16.2 \pm 1.2 \mathrm{c}$ & $17.3 \pm 1.2 \mathrm{c}$ & $18.2 \pm 2.1 \mathrm{~b}$ & $17.1 \pm 1.5 \mathrm{c}$ \\
$27 / 14$ & 6 & $28.6 \pm 2.5 \mathrm{~b}$ & $25.4 \pm 1.6 \mathrm{~b}$ & $24.4 \pm 1.1 \mathrm{~b} \quad 27.8 \pm 1.0 \mathrm{~b}$ \\
$30 / 11$ & 6 & $40.0 \pm 2.0 \mathrm{a}$ & $37.7 \pm 1.9 \mathrm{a}$ & $38.1 \pm 2.3 \mathrm{a}$ & $41.1 \pm 2.2 \mathrm{a}$ \\
\hline
\end{tabular}

temperature treatments, however, there was no systematic record of the color. The different preharvest temperature treatments had no significant effect on the storability of the tomato fruits (data not shown).

\section{Discussion}

A climate control strategy where high DT was combined with low NT, a DT of at least about $29^{\circ} \mathrm{C}$ combined with a NT of $11^{\circ} \mathrm{C}-12^{\circ} \mathrm{C}$, did not have a negative effect on the production and germination of normal pollen. Compared to the control treatment of $24 / 17^{\circ} \mathrm{C}$, this type of climate was often actually beneficial to pollen production and germination. This was concluded when the pollen was tested under plant growing conditions as well as under the same climate conditions in a growth chamber. Although the number of abnormal pollen under high DT/low NT increased, this was more than compensated by an increased number of normal pollen and increased germination potential. Sato et al. (2006) found that increasing the DT to $32^{\circ} \mathrm{C}$ combined with a NT of $26^{\circ} \mathrm{C}$ had a negative impact on pollen germination in tomato [8]. The maximum DT was higher and the NT much higher than that used in the present experiment. Energy reserves seem to be the predominant factor in determining pollen production as well as pollen viability [16]. Delayed ventilation and higher $\mathrm{CO}_{2}$ concentration accompanied higher DT, and this probably stimulated the photosynthetic rate. It has been reported that the negative effects of high day temperatures of up to about $30^{\circ} \mathrm{C}$ on photosynthesis can be minimized or eliminated by $\mathrm{CO}_{2}$ enrichment in roses [17,18] and cucumber [19]. Photosynthesis has also been found to be stimulated by higher growth temperatures when the $\mathrm{CO}_{2}$ concentration was increased [20]. The difference in pollen production in the fourth and sixth truss one day after opening might also be due to longer day lengths.

Table 5. Effect of different day/night temperature regimes during growth on firmness, dry matter (\%), soluble solids (\%), titratable acidity $(\%)$ and $\mathrm{pH}$ of three tomato cultivars at harvest and after seven and fourteen days of storage $(\mathrm{n}=6, \pm \mathrm{SD})$.

\begin{tabular}{ccccccc}
\hline Treatments & & Firmness & Dry matter (\%) & Soluble solids (\%) & Titratable acid (\%) & pH \\
\hline \multirow{3}{*}{ Day/Night temperature } & $24 / 17^{\circ} \mathrm{C}$ & $83.6 \pm 0.8 \mathrm{~b}$ & $5.55 \pm 0.04 \mathrm{a}$ & $5.12 \pm 0.04 \mathrm{a}$ & $0.450 \pm 0.006 \mathrm{a}$ & $4.18 \pm 0.01 \mathrm{~b}$ \\
& $27 / 14^{\circ} \mathrm{C}$ & $86.5 \pm 0.7 \mathrm{a}$ & $4.88 \pm 0.05 \mathrm{~b}$ & $4.64 \pm 0.02 \mathrm{~b}$ & $0.426 \pm 0.004 \mathrm{~b}$ & $4.18 \pm 0.01 \mathrm{~b}$ \\
& $30 / 11^{\circ} \mathrm{C}$ & $81.7 \pm 0.8 \mathrm{~b}$ & $4.89 \pm 0.04 \mathrm{~b}$ & $4.73 \pm 0.01 \mathrm{~b}$ & $0.403 \pm 0.003 \mathrm{c}$ & $4.23 \pm 0.01 \mathrm{a}$ \\
\hline \multirow{2}{*}{ Cultivars } & Capricia & $86.5 \pm 0.6 \mathrm{a}$ & $5.24 \pm 0.05 \mathrm{a}$ & $4.83 \pm 0.05 \mathrm{a}$ & $0.438 \pm 0.006 \mathrm{a}$ & $4.18 \pm 0.01 \mathrm{~b}$ \\
& Mecano & $84.0 \pm 0.5 \mathrm{a}$ & $5.11 \pm 0.06 \mathrm{ab}$ & $4.87 \pm 0.04 \mathrm{a}$ & $0.422 \pm 0.003 \mathrm{ab}$ & $4.21 \pm 0.00 \mathrm{a}$ \\
& Cederico & $81.2 \pm 0.8 \mathrm{~b}$ & $4.97 \pm 0.05 \mathrm{~b}$ & $4.78 \pm 0.03 \mathrm{a}$ & $0.418 \pm 0.005 \mathrm{~b}$ & $4.20 \pm 0.01 \mathrm{ab}$ \\
\hline \multirow{2}{*}{ Storage time } & 0 day & $89.1 \pm 0.5 \mathrm{a}$ & $5.17 \pm 0.06 \mathrm{a}$ & $4.84 \pm 0.04 \mathrm{a}$ & $0.427 \pm 0.004 \mathrm{ab}$ & $4.20 \pm 0.01 \mathrm{a}$ \\
& 7 days & $84.1 \pm 0.5 \mathrm{~b}$ & $5.14 \pm 0.06 \mathrm{a}$ & $4.88 \pm 0.04 \mathrm{a}$ & $0.435 \pm 0.006 \mathrm{a}$ & $4.19 \pm 0.01 \mathrm{a}$ \\
& 14 days & $81.7 \pm 0.8 \mathrm{c}$ & $5.01 \pm 0.06 \mathrm{a}$ & $4.79 \pm 0.04 \mathrm{a}$ & $0.417 \pm 0.005 \mathrm{~b}$ & $4.20 \pm 0.01 \mathrm{a}$ \\
\hline
\end{tabular}


Fruits developed at $27 / 14^{\circ} \mathrm{C}$ were firmer than fruits developed under other temperature treatments, and this might be related to the temperature-dependent activity of cell wall degrading enzymes acting on proteins and carbohydrates [21]. The difference in firmness between cultivars could be explained by variation in skin toughness, flesh firmness, and the pericarp/locular material ratio [22]. The firmness decreased during storage, which is most probably related to possible water loss and further ripening of the fruit. This is in accordance with the results of Jha and Matsuoka (2005), where a significant reduction in tomato firmness was observed during storage [23]. The red color of tomato fruit is determined by the amount of lycopene present in pericarp [24,25]. The optimal temperature for lycopene synthesis in tomatoes is in the range $16^{\circ} \mathrm{C}-21^{\circ} \mathrm{C}$, and a very high DT $\left(30^{\circ} \mathrm{C}\right)$ in the present experiment reduced the red color as visually observed, even if this high DT was compensated by $11^{\circ} \mathrm{C}$ NT.

The dry matter of fruit and vegetables is mainly composed of sugars and acids. Tomatoes usually contain 5\% $8 \%$ dry matter of which $4 \%-6 \%$ is soluble solids [9]. Citric and malic acids are the main organic acids found in tomato fruits and constitute approximately $10 \%-13 \%$ of the dry matter content [9]. In the present study, the dry matter content of the tomato fruits that could be associated with reduced soluble solids and titratable acids, decreased with increasing DT/decreasing NT. This reflects a somewhat reduced organoleptic quality of the fruits at high DT/low NT. The dry matter and soluble solids content of fruit mainly depends on the synthesis and transport of assimilates from the leaves to the fruits [26]. High temperatures are known to favor the distribution of assimilates to the fruits during fruit development [27], whereas low night temperatures have previously been shown to reduce the content of soluble solids in tomatoes [28]. For cherry tomatoes grown in greenhouses, an increase in sugars and a decrease in titratable acidity were observed in late harvest when the temperature and solar radiation peaked [12]. During storage, the content of soluble solids remained stable whereas the titratable acidity changed significantly. The stability of soluble solids during storage has previously been observed $[29,30]$ and the concentration of titratable acidity has been found to decrease [30] during a seven-day storage period.

\section{Conclusion}

It can be concluded that significantly larger variations between day and night temperatures than commonly applied will not reduce the pollen production and pollen germination potential in tomato as long as the mean temperature is kept constant. The overall conclusion was that the $27 / 14^{\circ} \mathrm{C}$ treatment was superior to the other two temperature treatments $\left(24 / 17^{\circ} \mathrm{C}\right.$ and $30 / 11^{\circ} \mathrm{C}$ DT/NT). The preharvest temperature regimes did not affect the storability of the tomatoes.

\section{Acknowledgements}

This project was financed by the Research Council of Norway. We would like to thank Ida Kristin Hagen, Dag Wenner, Signe Hansen and Kari Grønnerød for their technical assistance.

\section{REFERENCES}

[1] S. R. Adams, V. M. Valdes, F. A. Langton and P. J. C. Hamer, "Reducing Carbon Emissions from Greenhouse Production through the Use of Temperature Integration and Alternative Sources of Heat," Acta Horticulturae, Vol. 893, No. 1, 2011, pp. 95-101.

[2] N. Sigrimis, A. Anastasiou and N. Rerras, "Energy Saving in Greenhouses Using Temperature Integration: A Simulation Survey," Computers and Electronics in Agriculture, Vol. 26, No. 3, 2000, pp. 321-341. doi:10.1016/S0168-1699(00)00083-1

[3] O. Korner, M. J. Bakker and E. Heuvelink, "Daily Temperature Integration: A Simulation Study to Quantify Energy Consumption," Biosystems Engineering, Vol. 87, No. 3, 2004, pp. 333-343. doi:10.1016/j.biosystemseng.2003.11.003

[4] J. C. Bakker and J. A. M. Van Uffelen, "The Effects of Diurnal Temperature Regimes on Growth and Yield of Glasshouse Sweet Pepper," The Netherlands Journal of Agricultural Science, Vol. 36, 1988, pp. 201-208.

[5] B. J. Bailey, H. Challa, A. A. Risjdijk and J. V. M. Vogelezang, "Computers and Automation-Temperature Integration on a 24-Hour Base: A More Efficient Climate Control Strategy," Acta Horticulturae, Vol. 519, No. 1, 2000, pp. 163-169.

[6] R. G. Hurd and C. J. Graves, "The Influence of Different Temperature Patterns Having the Same Integral on the Earliness and Yield of Tomatoes," Acta Horticulturae, Vol. 148, 1984, pp. 547-554.

[7] A. Picken, "A Review of Pollination and Fruit Set in the Tomato (Lycopersiconesculentum Mill.)," The Journal of Horticultural Science \& Biotechnology, Vol. 59, 1984, pp. 1-13.

[8] S. Sato, M. Kamiyama, T. Iwata, N. Makita, H. Furukawa and H. Ikeda, "Moderate Increase of Mean Daily Temperature Adversely Affects Fruit Set of Lycopersiconesculentum by Disrupting Specific Physiological Processes in Male Reproductive Development," Annals of Botany, Vol. 97, No. 5, 2006, pp. 731-738. doi:10.1093/aob/mcl037

[9] M. Dorais, A. P. Papadopoulos and A. Gosselin, "Greenhouse Tomato Fruit Quality,” In: J. Janick, Ed., Horticultural Reviews, John Wiley \& Sons, Inc., Oxford, 2010. doi:10.1002/9780470650806.ch5 
[10] N. Gruda, "Impact of Environmental Factors on Product Quality of Greenhouse Vegetables for Fresh Consumption," Critical Review in Plant Science, Vol. 24, No. 3, 2005, pp. 227-247. doi:10.1080/07352680591008628

[11] D. M. Beckles, "Factors Affecting the Postharvest Soluble Solids and Sugar Content of Tomato (Solanumlycopersicum L.) Fruit," Postharvest Biology and Technology, Vol. 63, No. 1, 2012, pp. 129-140. doi:10.1016/j.postharvbio.2011.05.016

[12] M. A. Rosales, L. M. Cervilla, E. Sanchez-Rodriguez, M. Rubio-Wilhelmi, B. Blasco, J. J. Rios, T. Soriano, N. Castilla, L. Romero and J. M. Ruiz, "The Effect of Environmental Conditions on Nutritional Quality of Cherry Tomato Fruits: Evaluation of Two Experimental Mediterranean Greenhouses," Journal of the Science of Food and Agriculture, Vol. 91, No. 1, 2011, pp. 152-162. doi:10.1002/jsfa.4166

[13] M. Linke and H. P. Kläring, "Effect of Different Preharvest Conditions on the Postharvest Keeping Quality of Greenhouse Tomatoes," Acta Horticulturae, Vol. 654, 2004, pp. 213-219.

[14] A. N. M. De Koning, "Long-Term Temperature Integration of Tomato: Growth and Development under Alternating Temperature Regimes," Scientia Horticulturae, Vol. 45, No. 1-2, 1990, pp. 117-127. doi:10.1016/0304-4238(90)90074-O

[15] J. L. Brewbakerand B. H. Kwack, "The Essential Role of Calcium Ion in Pollen Germination and Pollen Tube Growth," American Journal of Botany, Vol. 50, No. 9, 1963, pp. 859-865. doi: $10.2307 / 2439772$

[16] N. Firon, R. Shaked, M. M. Peet, D. M. Pharr, E. Zamski, K. Rosenfeld, L. Althan and E. Pressman, "Pollen Grains of Heat Tolerant Tomato Cultivars Retain Higher Carbohydrate Concentration under Heat Stress Conditions," Scientia Horticulturae, Vol. 109, No. 3, 2006, pp. 212-217. doi:10.1016/i.scienta.2006.03.007

[17] D. R. Taub, J. R. Seemann and J. S. Coleman, "Growth in Elevated $\mathrm{CO}_{2}$ Protects Photosynthesis against High-Temperature Damage," Plant, Cell \& Environment, Vol. 23, No. 6, 2000, pp. 649-656. doi:10.1046/j.1365-3040.2000.00574.x

[18] L. M. Mortensen and H. R. Gislerød, "The Effect of High $\mathrm{CO}_{2}$ Concentrations on Diurnal Photosynthesis at High Daytime Temperatures in Small Stands of Cut Roses," European Journal of Horticultural Sciences, Vol. 77, No. 4, 2012, pp. 163-169.

[19] L. M. Mortensen and H. R. Gislerød, "The Effect of $\mathrm{CO}_{2}$ Concentration on the $\mathrm{CO}_{2}$ Exchange Rate in a Small Stand of Cucumber during Different Periods of the Day," European Journal of Horticultural Sciences, Vol. 77, No. 1, 2012, pp. 24-30.

[20] R. Besford, L. Ludwig and A. Withers, "The Greenhouse
Effect: Acclimation of Tomato Plants Growing in High $\mathrm{CO}_{2}$, Photosynthesis and Ribulose-1, 5-Bisphosphate Carboxylase Protein," Journal of Experimental Botany, Vol. 41, No. 8, 1990, pp. 925-931. doi:10.1093/jxb/41.8.925

[21] V. S. Meli, S. Ghosh, T. N. Prabha, N. Chakraborty, S. Chakraborty and A. Datta, "Enhancement of Fruit Shelf Life by Suppressing N-Glycan Processing Enzymes," Proceedings for National Academy of Science, Vol. 107, No. 6, 2010, pp. 2413-2418. doi:10.1073/pnas.0909329107

[22] D. M. Barret, E. Garcia and J. E. Wayne, "Textural Modification of Processing Tomatoes," Critical Reviews in Food Science and Nutrition, Vol. 38, No. 3, 1998, pp. 173258. doi:10.1080/10408699891274192

[23] S. N. Jha and T. Matsuoka, "Determination of Post-Harvest Storage Life of Tomato Fruits," Journal of Food Science and Technology, Vol. 42, No. 6, 2005, pp. 526-529.

[24] R. Arias, T. C. Lee, L. Logendra and H. Janes, "Correlation of Lycopene Measeured by HPLC with the L*, a*, $b^{*}$ Color Readings of a Hydroponic Tomato and the Relationship of Maturity with Colour and Lycopene Content," Journal of Agricultural Food Chemistry, Vol. 48, No. 5, 2000, pp. 1697-1702. doi:10.1021/jf990974e

[25] S. L. Molyneux, C. E. Lister and G. P. Savage, “An Investigation of the Antioxidant Properties and Colour of Glasshouse Grown Tomatoes," International Journal of Food Sciences and Nutrition, Vol. 55, No. 7, 2004, pp. 537-545. doi:10.1080/09637480400015828

[26] P. Riga, M. Anza and C. Garbisu, "Tomato Quality Is More Dependent on Temperature than on Photosynthetically Active Radiation," Journal of the Science of Food and Agriculture, Vol. 88, No. 1, 2008, pp. 158-166. doi: $10.1002 /$ jsfa. 3065

[27] A. N. M. De Koning, "The Effect of Temperature on Fruit Growth and Fruit Load of Tomato," Acta Horticulturae, Vol. 248, 1989, pp. 329-336.

[28] H. Qi, L. Hua, L. Zhao and L. Zhou, "Carbohydrate Metabolism in Tomato (Lycopersicaonesculentum Mill.) Seedlings and Yield and Fruit Quality as Affected by Low Night Temperature and Subsequent Recovery," African Journal of Biotechnology, Vol. 10, No. 30, 2011, pp. $5743-$ 5749.

[29] J. Javanmardi and C. Kubota, "Variation of Lycopene, Antioxidant Activity, Total Soluble Solids and Weight Loss of Tomato during Postharvest Storage," Postharvest Biology and Technology, Vol. 41, No. 2, 2006, pp. 151155. doi:10.1016/j.postharvbio.2006.03.008

[30] H. Auerswald, P. Peters, B. Bruckner, A. Krumbein and R. Kuchenbuch, "Sensory Analysis and Instrumental Measurement of Short-Term Stored Tomatoes (Lycopersiconesculentum Mill.)," Postharvest Biology and Technology, Vol. 15, No. 3, 1999, pp. 323-334. doi:10.1016/S0925-5214(98)00094-5 